\title{
Hinduism and its Symbols
}

\author{
I. C. Licyamma ${ }^{1}$ \\ ${ }^{1}$ Professor of Social Work, Srinivas Institute of Management Studies, Pandeshwar, \\ Mangalore - 575001 .
}

Type of the Paper: Research Paper.

Type of Review: Peer Reviewed.

Indexed in: OpenAIRE.

DOI: http://dx.doi.org/10.5281/zenodo.439776.

Google Scholar Citation: $\underline{\text { IJMTS }}$

\section{How to Cite this Paper:}

Licyamma, I. C. (2016). Hinduism and its Symbols. International Journal of Management, Technology, and Social Sciences (IJMTS), 1(1), 14-20.

DOI: http://dx.doi.org/10.5281/zenodo.439776.

International Journal of Management, Technology, and Social Sciences (IJMTS)

A Refereed International Journal of Srinivas University, India.

(C) With Authors.

\section{(c) (i) (9)}

This work is licensed under a Creative Commons Attribution-Non Commercial 4.0 International License subject to proper citation to the publication source of the work.

Disclaimer: The scholarly papers as reviewed and published by the Srinivas Publications (S.P.), India are the views and opinions of their respective authors and are not the views or opinions of the SP. The SP disclaims of any harm or loss caused due to the published content to any party. 


\title{
Hinduism and its Symbols
}

\author{
Dr. I. C. Licyamma ${ }^{1}$ \\ ${ }^{1}$ Professor of Social Work, Srinivas Institute of Management Studies, Pandeshwar, \\ Mangalore - 575001 .
}

\begin{abstract}
Man has succeeded very much in going outside of himself and has made many achievements. He has travelled through the space, found out many machines, many stars etc.But man has not succeeded as he must have done in one field except a very few who have really searched within and transformed themselves and others into great self-realised,contented human beings, who are not moved by the pleasures and pains of life The epic character Nachikethas is a best example of this field's best motivator.India's epics are the greatest recorded epics known to man.It has been said that nothing exists that cannot be found in the epics of India. Bhagavat Geetha is the song of God.This literature continues to enchant readers and scholars the world over. This paper is an effort to search in a very limited way the spirit of this culture and its treasures.I bow down to the great power which is the power behind the entire existence.This power is smaller than the smallest and bigger than the biggest. Symbology is very common in all the ancient literature and epics. This paper is an effort to inculcate more interest in the present generation about the beauty and highly esteemed principles and values of the characters of the epics and the reality of life.
\end{abstract}

Keywords: Enchant, Palatable, Turbulent, Vibrate, Revolution.

\section{INTRODUCTION :}

Hinduism is not a mere religion. It is a way of living. There are different strata of way of living for different types of people. So it is suitable for Pamaras and Pandithas. That means it is suitable to all types of illiterate people and all types of highly scholarly fellows .It is the mother of all religions. It is so interesting to note that its usage of symbols from ancient time onwards. Many of its symbols were adapted by many other religions and other groups. For example the famous Sudarsana chakra was adopted by ancient Jews. It is the intersection of two triangles upward and downward. The country of Israel in their National flag put this symbol. The meaning of this symbol is that downward triangle represents God's grace and countless insights descending on humanity (Bhagavan, 1993). This grace of god will help and promote to ascend man towards God. Without the grace of the Supreme power no human being can ascend towards God. This wonderful representation through symbology is a great explanation. Many other religions and especially Adolf Hitler understood the importance of Swastika symbol. He adopted swastika as a Nazi Symbol (S.K. Ramachandra Rao, 1988). He was a great success in the beginning. Germany became a mighty Nation. He was a vegetarian, non-smoker and non-drinker. If he had selected a very positive political track he would have been a wonderful success. His egotism -creed for power, cruelty to fellow beings made him a great failure. He misused the symbol and after a particular period it reacted and made him a through failure. If he had purity of mind and integrity he would have been a great success in history (SankaranNamboothiriPadu, 2009). His vegetarianism and other good habits promoted his power by the use of Swasthika symbol.Misusing a symbol without purity definitely will react.It is like 
using black magic in AtharvaVeda. Through negative use of symbol in ancient days certain people practiced black magic and they used it for killing purpose,paralysing a person,seduction of ladies etc.This type of practice is called Marana,Sthambhana and Vasya. But after a period it reacted and they suffered maximum for their diabolic deed (S.K. RamachandraRao, 1998).

Hinduism is a way of life which contains different ways of living according to the status of the person. From time immemorial to the present it is using different type of symbols for worshipping God to attain physical,mental,spiritual or esthetical achievements.

\section{WHAT IS THE REAL MEANING OF HINDU:}

Many people are considering it is a religion of Indus valley people.From Indus culture the term Hindu derived.It is not like that.Our Devanagarialphabet is based on real phonetics as it is. These sounds were heard by yogis in their Anthara chakras that is different nerve plexus. The chakra means knots of nerve fibres in different level.Two main nerve lines are passing through in a human body one is spinal cord and that is called as SushumnaNady, which is passing inside the vertebralcolumn.It has got the protection of vertebral column. The other cord is vagus nerve and passing through inside the body without any protection of bone covering.Both of them originate from the base of the brain.In vertebral column certain places have small holesthrough them branches of nerve comeout and at the same level in the vagus nerve. Branches are taking place and they knot together and it makes a chakra.

\section{CHAKRAS :}

According to yogis there are six chakras. They are mooladhara, Swadishtana, Manipuraka, Anahata, vishuthi and Sahasrara. Mooladhara exist around base of the spinal nerve.Manipuri exist somewhat in the middle point between navel and the vertibra.Anahat exist in the middle point between spinal colomn and between the midpoint of nipples. Vishuthi near about throat. Sahasrara exist exactly in the middle of the brain. There is an opening centre of the Sahasrara that exist at the root of the nose. It is called Trikotti or Aagnayachackra. A pin point hit on this spot will cause death to an individual. Eastern system of hypnotism is using this point as the power transferring centre.In yoga yogis are concentrating their eyes to this point. This is called as Sambavi mudra. When exactly this mudra will take place a person will feel a white light throughout his body and outside (KesavaPillai K.C., 1972).

\section{EXPERIENCE OF SOME YOGIS :}

God is lightless light and darkless dark.But man can only experience God through this white light,By Continuous experience of this whitelight yogis can live thousands of years.It is mentioned in the Autobiography of a yogi by YoganandaParamahamsa that BabagiMaharajin Betharinath is more than two thousand years old (RigvedaDarsana, 1998).

My guru Prabhakara Siddhayogi or Pampatti Siddhaas known in Tamil Nadu lived more than 750years.He was a great yogi and got Samadhi after 750years.He told me pranayama means gradual extending in breathing and stopping. It is not alternate breathing between nostrils by closing and 0pening it.By this Pranayama a yogi can live any number of days without breathing and he will not die.This part needs lot of explanation and it is very difficult to find space in this article.

As Devanagarilipi starts from Aha andend in ha that is Aham that is ego-All the physical meaning came from this Aham.Ha-kara is the maximum crudificationpoint. When we put e-kara on this Ha -kara it will transform into final 
entity and tends to Amruthasabtha. Nakara joint with the creative resonance dakara join with Saktibeeja u-kara'. In total the crude physical entity will be transformed into divine entity byputting the creative resonance E-Kara.This is the real meaning of the term "Hindu".

We can come to the point symbolism.There are different Hindu Gods Siva, Brahma, Vishnu, Ganapathi etc. They are mere symbols to represent different powers of God.First we can take Siva.When we produce the sound Sh-It reminds to be silent, That means we arelooking to the consciousness the witnessing counterpart in us that makes real all our activities. Actions are made real due to a witnessing entity. The entire cosmos is a reality due to a witnessing entity that is called Siva. As we mentioned earlier these sound remind us the witnessing entity the reflective counterpart Sakti will take place. That is "Kali”. Kakara represents Akasha,La-Kara represent the creative dancing resonance. According to tanthraLa-kara andlla-kara same. Thus Kali means one who creates dancing resonance in Akasha that is the meaning of this symbol Kali. In the witnessing entity E-Kara creates and Vimarsha in the purusha takes place. Thus creation starts 'Va' is anandabeeja. By creation the supreme God enjoys. That is the meaning of Siva.

\section{SYMBOLOGY}

Hindus are worshipping different types of Gods.As I mentioned earlier we can interpret different Gods and its symbolic representation.It is impossible to grasp and comprehend infinite God into our limited mind.So rishis invented the best way to approach the infinite through symbology.It is impossible for the mind to understand infinite ideas.But symbols will transform this mind to the shore of infinite.We can take the symbol Ganapathi.Ga-kara means Anthakarabeeja. Nna-kara means reaching to Anthakarabeeja.
Pathi means the leader.In total the Lord of the total crude physical entities. In this total physicality there is hidden God power. If anybody wants to rise above this physicality then this crude force will pull him downwards that is called Vigna (blocks). When we salute Ganeshathen that power will remove the blocks and help us to attain perfection. Ganapathi's vehicle is rat. Its physical form is the joint form of man and elephant.Yogis explaining the theory of evolution in a very beautiful symbolic aspect from small mouse all mammals underwent evolution and reached the stage of man and elephant (Darwin C., 1859).When we meditate on this symbol unknowingly all spiritual evolution will take place. About the higher things mind can understand only through symbols and these symbols will lead him to higher strata of existence.The beautiful symbology and romantic concepts in Hinduism is so wonderful and marvellous (Chinmayananda, 1992).

\section{MAHABHARATHA, BHAGAVATHA AND RAMAYANA}

Bhagavatha,Mahabharatha andRamayana are allthe symbolic and romantic concepts of higher ideas. In order to make ordinary people to higher levels of existence yogis put these ideas into story forms.Thus they made it palatable to the common people. When we want to give bitter medicine to our children we will give it to them with sweet things,like wise they did.The common man is not a fool alldivine potentialities are hidden in him.Using story and symbolology yogis are promoting his inner powers (Prakasam, 1968). Mahabharatha,Bhagavathemand Ramayana are great stories mixed with Romantic concept andsymbology (Ezhuthachan, 2001).

\section{PURANAS}

There are 18 beautiful Puranas.They excel in literary qualities.They are, 1. Vishnupuranam 
2. Bhagavathapuranam

3. Naradeeyapuranam

4.Garudapuranam

5. Padmapuranam

6.Varahapuranam

7. Brahmapuranam

8. Brahmandapuranam

9. Brahmavyrthapuranam

10.Markandayapuranam

11.Bhavishyapuranam

12. Vamanapuranam

13. Vayoopuranam

14. Linkapuranam

15. Skandapuranam

16. Agnipuranam

17. Mathsyapuranam

18.Koormapuranam(Ezhuthacan, 2001).

The epic Mahabharatha written by Vyasais so wonderful with symbolic representation. Various aspects of knowledge are narrated in it .It is a treasure house of knowledge with practical wisdom.Romantic concept in Mahabharatha far excels any other concept.The name of SreeKrishna itself is a great symbolic representation.Ka-kara means Akasa.Ru-Kara means Agni.Sakaraand sha-kara are the same that denotes Siva. In total one who put Ru-kara in akasabeejaKa-kara by igniting it reach siva point.There are different types of Akasa among them Mahakasa and Daharakasa etc. among them Daharakasa is inside body that means inside the shoonya spaceof spinal chord(A.P.J.Abdul Kalam\&Dr.A.SivanthuPillai, 2004).

\section{SERPENT POWER :}

In the Sushumna nerve the middle part is Shoonya that is empty.ThisShoonya is called Daharakasha. Normally it is silent.In a human being in normal stage,through the physical flesh part,motor and sensory currents are passingthat activates a human body in motor and sensory experience.So hewill be always awake in the crude physical world .This is not an ultimate reality.When a Yogi will do continuous meditation at a certain level his kundalni power (serpent power)will awake and pass through this inner Akasha with a hissing sound and reach Siva point at the centre of the brain.Then thousands and thousands of white lotus flowers dances with radiant white light brilliance.This is Samadiwith supreme bliss.Lotus flower symbolically represents trillions of braincells.Coiled Serpent power represents potential energy.Awakening stage is the kinetic energy which passes through inside Daharakasa -Siva point in the midbrain existing in hypothalamus which controls all the glands in the body.It is the centre of the lotus flower.It is the fertilisation point.The lady power Sakti unite with Siva in the centre that is the pollination point of Siva and Sakthi.Through this man get a divine birth.This is called Tharaka Brahma Samboodi.One who reaches this point can take birth in the physical world with his own will.When such birth will take place and a total upheaval of spiritualisation willvibrate in this world.Sri Krishna is an example for this (Sir John Wood Roffe, 1991).

\section{GEETHA :}

In normal case each human being will take birth according to his or her karma.(actions). According to this concept he advised Geetha to Arjuna in the war field.It is also symbolical. War symbolises this turbulent physical world. In the midst of that war by discretion he must be detached to the fruit of action and attain God.Geetha is a beautiful song sung by the divine and transmitted to Arjuna for the entire world (Jawaharlal Nehru, 1946).It is igniting Anthakarabeeja.Ga-kara with creative power of E-Kara and transforms it to Thakara that is God. It teaches us the perfect detachment to this world and perfect attachment to the Lord Supreme. Krishna means igniting Agni in Daharakasa by which attaining Siva point. The great symbology is beyond any human explanation. Here the mystery and 
symbology excel beyond any explanation. Bharatha means through the play of brilliant fire reaching Tha-kara that is God.If I will write about symbology it will never stop.I am pressurised to stop this article otherwise it will go on.

\section{CONCLUSION:}

English poet T. S. Eliot(1992) appreciated the symbolism of Hinduism. Among there symbols he was my much impressed by the symbol of lotus flower. Lotus is rooted in mud. But the flower is open above the water surface. The represents symbol represents that even though we are living in the mud, mundane world our mind and spirit must be opened to the pure sky.All gods and goddesses sit on the lotus flower.It points out our mind must be always in the pure entity that is God.TharakaBrahma Sambhoodi is a wonderful philosophical concept and an excellent example of symbolism.God is an infinite circle.All living beings are limited circles.By spiritual evolution when this small circle touches the circumference, its circumference is a straight line because it is an infinite circle. When this small circle touches the circumference that becomes a straight line. This is called Tharakabrahma. He is in both the spheres i.e. the divine sphere and the mundane sphere.He can take birth in any human form according to his sweet will, not by Karma.Lord Krishna is an example of this.Through this symbiology all the mystical and philosophical ideas of Hinduism is put in a beautiful way.It is a far excellence of symbolism.In Upanishad especially in Kadopanishath they used this symbol lavishly.All the 18 epics as I mentioned earlier and all the Upanishads are all symbolical expressions to digest and accumulate higher ideas.

\section{REFERENCES}

[1] A.P.J.Abdul Kalam \& Dr.A.Sivanthu Pillai. (2004).Envisioning an Empowered Nation.

[2] Bhagavan, (1993). Gods- A
Conception. Published by SreeTarama Foundation, Ahmadnagar, India.

[3] Ezhuthachan,(2001.) Adhyatma Ramayanam D.C.Books. Tata McGraw Hill Publishing Company Ltd., India.

[4] Jawaharalal Nehru(1946). Great Englis(h Poet T.S.Eliot India.Penguin books India Pvt.Ltd.

[5] Kesava Pillai K.C.(1972). Jyothisha GurubhuthanVidyarambham Press \& Book Depo, Alleppey, Kerala.

[6] S.K. RamachandraRao,( 1988.) Rigveda - Darsana. UBS Publishers \& Distributers Ltd.

[7] Swami Chinmayananda (1992). The Holy Geetha. Chinmaya Mission Trust.Jak Printers Pvt. Ltd., Mumbai, India.

[8] Sir John Woodroffe (1991). $7^{\text {th }}$ Edition, Principles of Tantra (2 Vol.)Edition : Ganesh \& Co., 38, Tanikchalam Road, Madras - 600 017.

[9] VyasaMahabharatham.Translated by PrakasamK. (1968). D.C.Books. Kottayam, Kerala.

[10] Sreechakra Puja, Sankaran Namboo thiri Padu. (2009). Panchangam Press, KunnamKulam.

[11] Swami Vivekananda (1989). Swapna Printing Works Private Limited, Calcutta, India.

[12] T.S.Eliot (1922). The Waste land history year by year. D.K. Books, London, Delhi.

[13] Darwin C., (1859). The Origin of Species, London.

[14] Tagore (1912). Gitanjali, Song Offerings.Hisotry year by year.D.K. Books.

[15] Bertrand Russell (1946). A history of Western Philosophy. George Allen and Unwin, U.K. 
[16] M.K. Gandhi (1947). India of my Dreams. Navajeevan Publishers Hou se.

[17] Swami Tejomayananda (2003). Awakening Indians to India. Central Chinmaya Mission Trust.

[18] Mystical Approach in the Upanishads (1975). MahendranathSarcar, M.A., Ph.D. The Cultural Heritage of India published Ramakrishna Mission, Calcutta. 